\title{
Modeling of upset forging process of bars fixing the head of the traction concrete poles
}

\author{
Modelowanie procesu spęczania prętów \\ mocujących głowicę betonowych słupów trakcyjnych
}

MICHAL TAGOWSKI
MICHAL PYRC
ANDRZEJ ZABORSKI *
DOI: https://doi.org/10.17814/mechanik.2017.7.95
The upset forging is a method of manufacturing, which aim is to improve the mechanical properties of the workpiece and to give it the desired shape. In order to meet the requirements for mechanical properties and dimensional and shape characteristics of the product, the device should be equipped with a suitable socket and a tool. Also the parameters of the process must be properly selected. The article presents the method of modeling the process of the upsetting of a bar, used to design and build the forging machine, along with the tooling and used to determine the parameters of the upsetting process.

KEYWORDS: upset forging, numerical modeling, FEM, Abaqus, traction concrete poles

One of the methods of industrial production of prefabricated concrete elements for electric power engineering is the technology of centrifugal compressed concrete [1]. An excellent example of this type of product is the power poles of overhead power lines, lighting posts, multipurpose support structures, called towers, or ETG railroads currently being marketed by StrunobetMigacz [2]. The posts of this type, as well as other products manufactured in compressed concrete technology, may require the use of, during the production itself, a permanent connection of additional steel elements to the concrete structure of the product through internal reinforcement. The ETG (fig. 1) rail or tram track is at the base equipped with a steel plate, often called a head with holes to which steel reinforcement is attached, and at the same time forms a base for fixing the concrete element through a threaded connection to the concrete foundation (pile, wall plate).

If necessary, a permanent connection of the reinforcement with the steel head and its rapid preparation on the production line, the welding method or the threaded connection may be replaced by a method of threading the free end of the round rod through a graduated opening in the head and then on the swelling

\footnotetext{
* Dr inż. Michał Tagowski (michalt@itm.pcz.pl), dr hab. inż. Andrzej Zaborski prof. PCz (zaborski@itm.pcz.czest.pl) Politechnika Częstochowska, Wydział Inżynierii Mechanicznej i Informatyki, Instytut Technologii Mechanicznych, ZAPiT; dr inż. Michał Pyrc (pyrc@imc.pcz.czest.pl) - Politechnika Częstochowska, Wydział Inżynierii Mechanicznej i Informatyki, Instytut Maszyn Cieplnych, ZMTiTS
}

of the rod and pressing go into the nest. Sometimes this method becomes the only way to ensure a lasting connection, which is due to the specificity of the material used (fragile, hard, non-consumable). The authors of the article have developed an industrial hydraulic system, a microprocessor-controlled device for the expansion of reinforced ribbed bars (fig. 2).

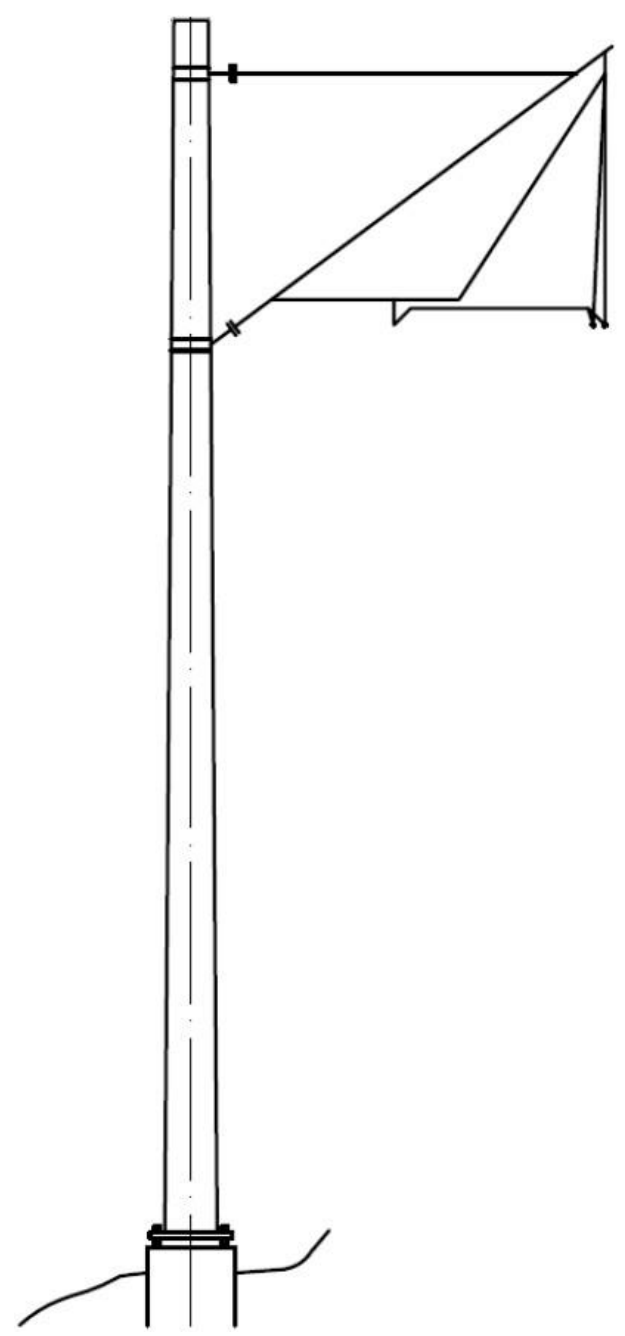

Fig. 1. ETG railway track with the head visible at the base [2] 


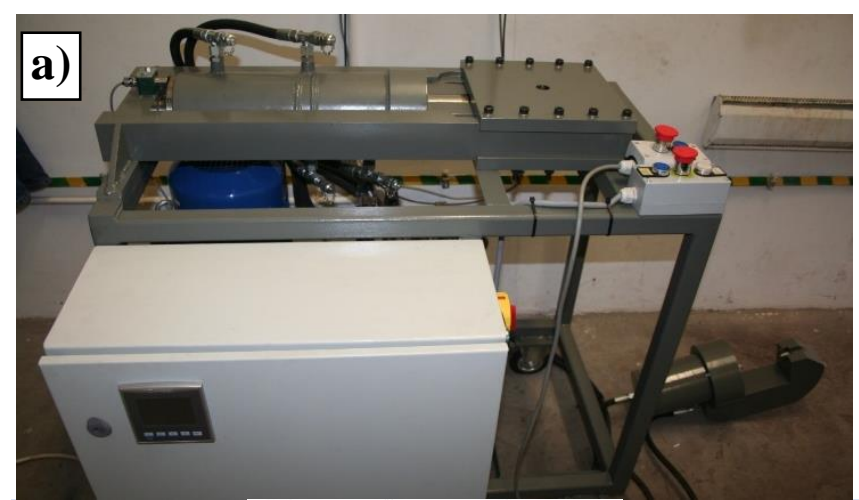

b)

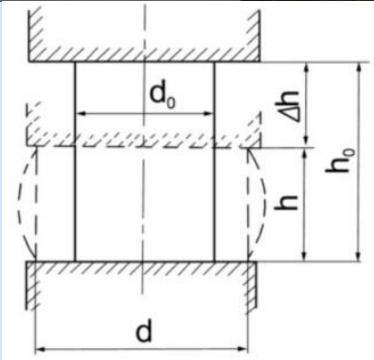

Fig. 2. Hydraulic forger with microprocessor control at the test bench (a) and cross section of the workpiece during the upset forging (b) [3]

The increase in cross-section at the expense of the height or length of the element during the process under the influence of a suitable press or hammer impact is called a swelling. The cylindrical shape changes in the shape of a barrel.

\section{Modeling the process of bar upset forging in the Abaqus solver}

For example, a smooth bar with a diameter of $\varnothing 12$ made of B500SP material with a characteristic yield strength $\geq 500 \mathrm{MPa}$ was considered. You can create a swollen bar in the Abaqus CAE CAD editor or import from an external modeler. If the model has been imported, the scale tab should include the scale and units, in which the model was built.

\begin{tabular}{|c|c|c|c|}
\hline Create Part fro & m ACIS File & & \\
\hline Name - Repair & Part Attributes & Scale & \\
\hline Name & & & \\
\hline Part name: tem & p-Fi12-new & & \\
\hline Topology & & & \\
\hline (-) Solid $\bigcirc \mathrm{Sh}$ & eell Wire & & \\
\hline Part Filter & & & \\
\hline (9) Import all pa & & & \\
\hline Combine & into single part & & \\
\hline Stitch & edges using toler & rance 1 & \\
\hline (9) Create inc & dividual parts & & \\
\hline Import part $n$ & number 1 & & \\
\hline OK & & Cancel & \\
\hline
\end{tabular}

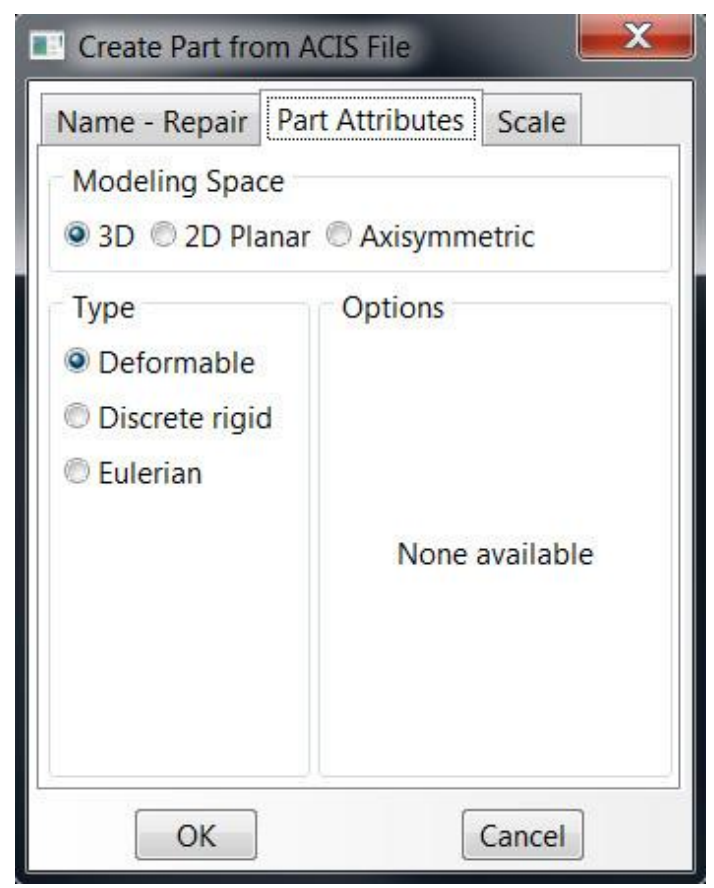

Fig. 3. Model definition in the Model/Part branch - Abaqus CAE

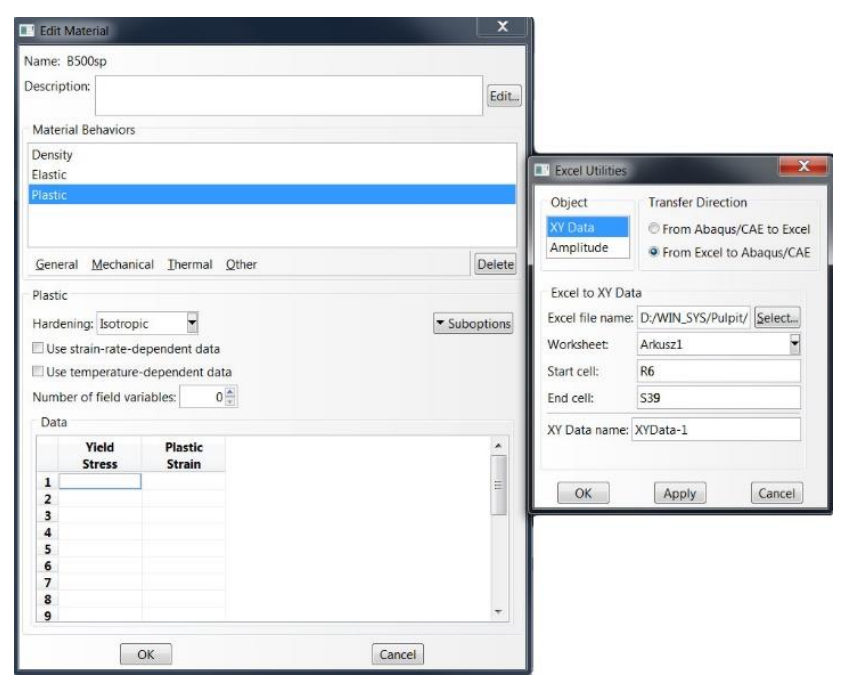

Fig. 4. Import of material data

After geometry is created, the material and material sections must be defined. The material can be defined directly in the Materials branch or in a spreadsheet. Then place the data in the Material section. When importing data from a spreadsheet into the CAE environment, use the ExcelUtilities tool to enter the address and range of fields in the sheet where the data is stored (fig. 4). In the case of creating a inp batch file, place the Materials section with the appropriate properties (* Density, * Elastic, ${ }^{*}$ Plastic).

The next step is to create the calculation steps (Steps branch) and the assembly details in Assembly [4]. Individual models should be added as instances linked by constraints - just as in the classic case of a 3D modeler. In addition, you must specify whether the finite element mesh is to be built from the part level (branches: Parts/Mesh name) or from the instance level (branch: Assembly/Instances/Mesh Name). In the case of a perfectly rigid piece, add reference points whose properties will be transferred to all nodes of the grid. In addition, if necessary (due to occurring moments, motion 
conditions or rotational inertia), the reference point must be moved to the center of mass of the workpiece.

After creating the assembly, you must define the contact properties between the components using the interaction module (fig. 5). The contact properties can be defined as friction and slip, as well as contact types (hard, soft and suppressed). In addition, the properties may include data on: attenuation, thermal conductivity, thermal radiation, and heat generated by friction. Contact can be defined in three ways, ie as a general contact, surface-contact and self-contact. A general contact allows you to specify the interactions between several or all regions of a model in question using a single definition. The surface-area interface allows you to define the interaction between two deformable surfaces or between a deformable surface and a perfectly rigid surface. The self describes the interactions that occur in different areas of the same surface. All three types of contact may occur together in one simulation, provided that only one general contact definition is active during the individual analysis steps [5]. In case of upset analysis, two definitions of contact are used: surfacearea between piston and rod.

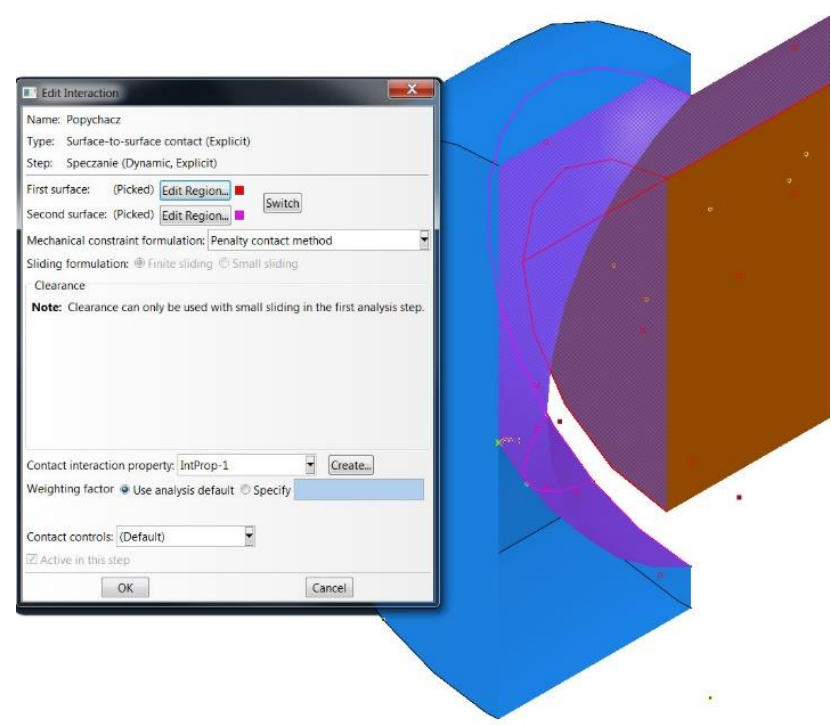

Fig. 5. Definition of surface-surface contact

Then you should build finite element mesh for each instance. The model consists of four parts: two clamping jaws, a piston and a swollen rod. For the analysis of the swelling of the rod as a deformable body, only a test rod of diameter $\varnothing 12$ was adopted. The remaining parts are defined as perfectly rigid bodies.

In the mesh module, the first step is to define the length of the interstitial edge. The smaller it is, the more accurate the geometry is. Select the Global Seeds tool and specify the geometry (fig. 6).

Then, in the Approximate global size field, enter the distance value - according to the adopted layout of units. In addition, this tool allows the user to apply the curvature control according to the assumed criterion of the deviation index $h / l$ (fig. 7 ), which defines the value of the deviation of the mesh edge from the actual curve in two coordinates (fig. 7). Curvature control allows the grid to be smoothed out when complex geometry is used.
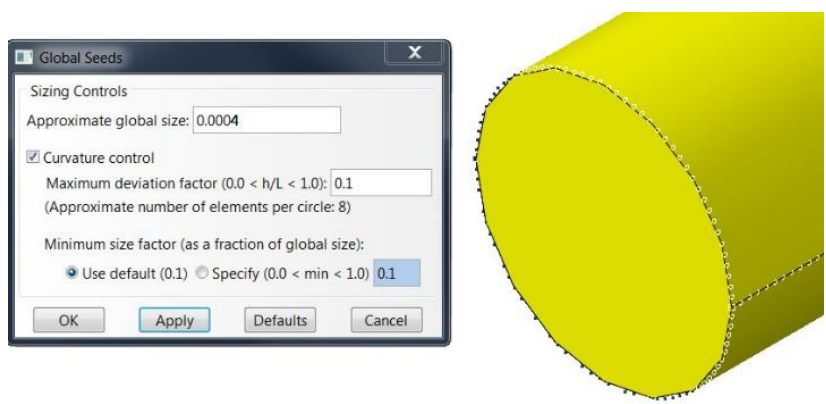

Fig. 6. Global Seeds tool and overlapped nodes

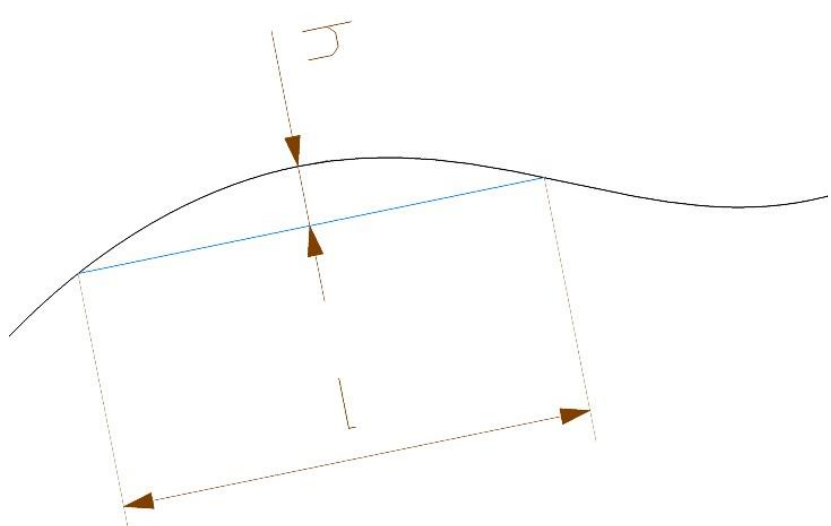

Fig. 7. Variations of the curvature of the model $-h / l$

The next step after adding nodes to the model is to choose the shape and type of the finite element. The tools responsible for these functions are Assign Mesh Controls (Assign Mesh Controls) and Assign Element Type (for selecting the component family and their properties). The pistons and the clamps - as rigidly rigid bodies - a grid of triangular elements (R3D3) was applied, and on a swollen rod - cube 8 cubes (C3D8R).

The tetrahedral and cubic elements are universally used in grid generator algorithms. Easy to describe complex shapes with the help of tetrahedral meshes, however, because the derivatives of the shape function are constant relative to the volume of the element, the derivative results obtained in such elements can be very inaccurate. In case of high stresses and deformations, use cubic meshes. The view of superimposed nets is shown in fig. 8.

For rigid parts, the mass (and not the weight, as Abaqus does not have a built-in unit system, so it is necessary to use the basic units) centered at the reference point (whose properties are assigned to the entire workpiece). In order to allow the movement of details in the model, they must be assigned appropriate boundary conditions and loads in each direction. Each of the loads can be either constant or depending on the defined amplitude. The boundary conditions and loads are defined in the corresponding section of the batch file. One can also use the CAE manager (fig. 9). 


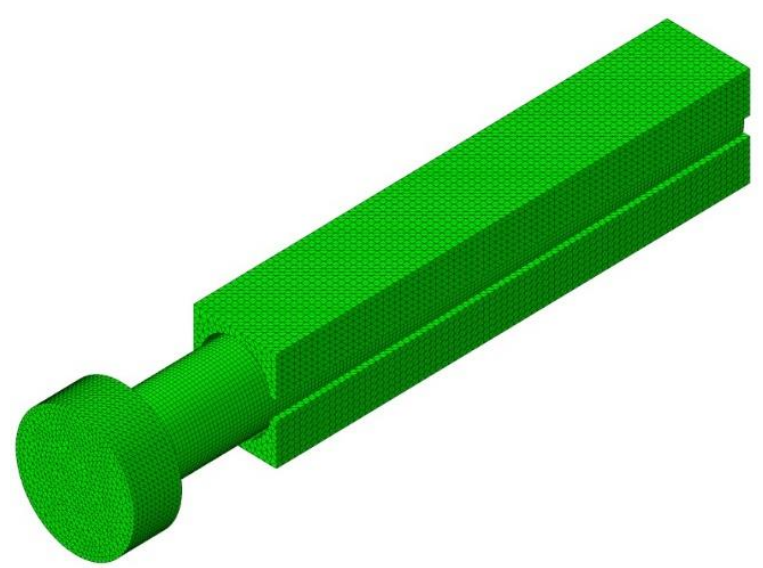

Fig. 8. Finite element mesh constructed based on geometry of individual parts

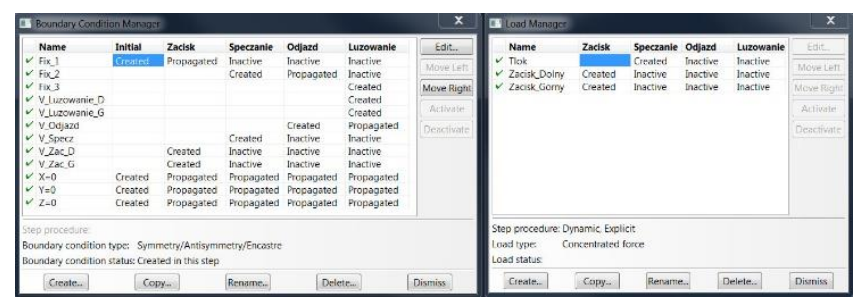

Fig. 9. Definitions of boundary conditions and loads - CAE environment

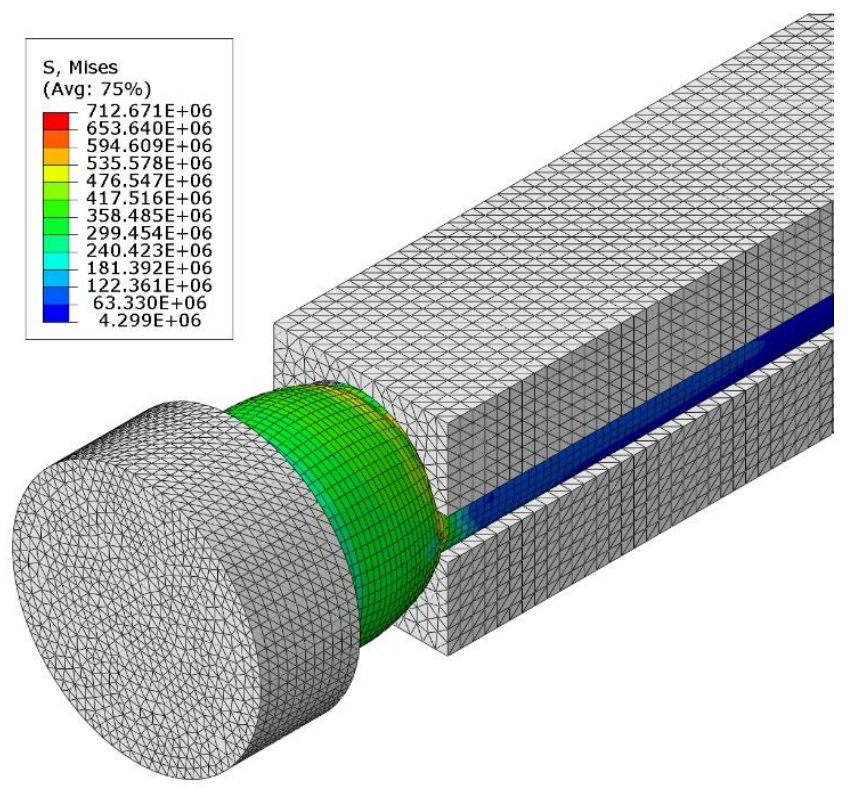

Fig. 10. Calculation Results - Abaqus Viewer

In order to perform the calculations, you have to specify the calculation task - the parallelism broken down by the CPU's, the number of domains and the parallel processing type - and reserve the RAM volume. After performing the calculations, the results can be visualized both from the CAE level and from the browser command line (Abaqus Viewer - fig. 10).

\section{Conclusions}

The possibility of modeling the upsetting of the rods is a great convenience in the process of designing additional tooling of the compressor - clamping jaws or forming piston jaws. Simulation of the process using the finite element method allows not only to carry out the strength analysis of the entire operating system, but also to select the operating parameters of the device. Changing the geometry of the molding socket on the plunger and the process parameters at the design and analysis stage of FEM can predict the shape of the resulting rod end and adapt it to the industrial applications in question.

The method of fixing the steel rod in the head was reported to the Patent Office [6]. Researchers at the present time concentrate on optimizing the work of the compressor, modeling the occurrences in the swollen rods and testing various punches and clamping jaws for different types of reinforcement bars.

\section{REFERENCES}

1. Gruca Michał, Pyrc Michał. 2014. „Badania drgań w łożyskach podporowych wirówek do produkcji strunobetonowych żerdzi wirowanych". Logistyka 2/2014.

2. Katalog wyrobów Strunobet - Migacz, www.strunobet.pl.

3. Sińczak Jan. 2010. Podstawy Procesów Przeróbki Plastycznej. Kraków: Wydawnictwo Naukowe AKAPIT.

4. Sobiepański Michał, Tagowski Michał. 2013. „Przygotowanie zredukowanego modelu przekładni zębatej z zastosowaniem oprogramowania Simulia ABAQUS". Mechanik R.86 7/2013.

5. Abaqus 6.10 Analysis User`s Manual

6. Zgłoszenie patentowe: Połączenie żebrowanego pręta stalowego z płytą metalową i sposób łączenia żebrowanego pręta stalowego z płytą metalową w produkcji elementów $\mathrm{z}$ betonu zbrojonego; PL403484(A1)-2014.04.14 i SK 500252012 A3 